\title{
The Effectiveness of Discovery Learning Model in Writing Descriptive Text
}

\author{
Widayanto \\ Religius Education and Training Center Surabaya, Indonesia
}

\begin{tabular}{|c|c|}
\hline (A) check for updates ${ }_{\text {OPEN }} \partial_{\text {access }}$ cC) (i) (2) & DOI : https://doi.org/10.46245/ijorer.v2i2.92 \\
\hline Sections Info & ABSTRACT \\
\hline Article history: & \multirow{10}{*}{$\begin{array}{l}\text { This study is intended to describe the effectiveness of the application } \\
\text { of discovery learning model in writing Descriptive texts. Learning } \\
\text { process in education and training field is less related to daily life so } \\
\text { that the participants are less passionate and bored. The learning } \\
\text { process is still centered on the Widyaiswara/instructor (teacher } \\
\text { centered). The problem examined in this paper is whether the } \\
\text { discovery learning Model effective in improving the learning } \\
\text { outcomes of training participants in the English Teacher Training } \\
\text { class in writing Descriptive texts. This research used the Quasi } \\
\text { experiment method, conducted at the Surabaya Religious Education } \\
\text { and Training Center. Madrasah Aliyah Class I English teacher } \\
\text { training class was as a control group while Madrasah Aliyah Class II } \\
\text { English teacher training class was as an experimental group. Data } \\
\text { obtained through four types of instruments: (1) achievement test, (2) } \\
\text { observation, (3) interview, and (4) questionnaire. Data of test results } \\
\text { analyzed using t-test statistics. The results showed that the discovery } \\
\text { learning model can improve the learning outcomes of participants' } \\
\text { products and processes. Discovery learning model can be used as an } \\
\text { alternative learning to write descriptive text. }\end{array}$} \\
\hline Submitted: January 31, 2021 & \\
\hline Final Revised: February 20, 2021 & \\
\hline Accepted: March 21, 2021 & \\
\hline Published Online: March 31, 2021 & \\
\hline Keywords: & \\
\hline Discovery Learning & \\
\hline Learning model & \\
\hline Writing Descriptive Text & \\
\hline 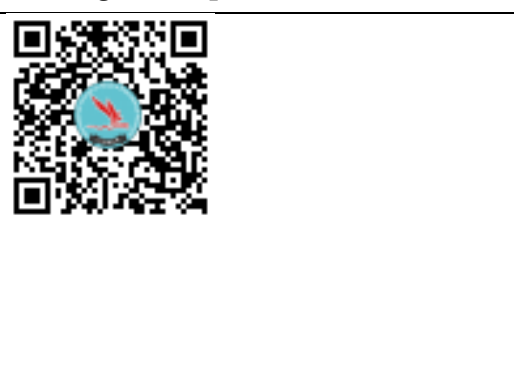 & \\
\hline
\end{tabular}

\section{INTRODUCTION}

The implementation of the new curriculum is very encouraging for writing lessons, because writing is equal in proportion to the other four language skills, including writing descriptive text lessons. However, this joy was followed by a certain kind of confusion for most teachers in the field when writing lessons took place (Sayuti, 2014). Descriptive text is a type of text which contains a detailed description of an object. The objects are various, such as people, places, and things. The purpose of the descriptive text is to make the reader feel as though the writer has written (Prasetya et al., 2020).

Learning English writing descriptive texts has a fundamental essence and substance. In relation to the efforts to cultivate students' four language skills (listening, speaking, reading, and writing), it is intended that they can communicate internationally in facing the global world (Brown, 2008). For this reason, teachers as learning actors must be able to foster and develop student activeness and creativity in English writing lessons by applying various methods, approaches and learning models, even though the reality shows that this has not been fully implemented. Indications of this last trend can be seen from the learning process that develops during the process of learning English, where the class tends to be passive. The learning profile of students is more in the learning behavior of listening to information activities (Kartika et al., 2020) with dominant teacher activities and taking many positions in front of the class who tend to "patronize", rather than teaching students to learn to think about subject matter (Al Muchtar, 2012).

Therefore, the method or approach used by the teacher in the learning process should not only refer to one particular method or model, which is more by using dry monotone 
lectures that emphasize the grammar translation method throughout the semester or even throughout the school year, without being combined with other methods or models, even though the objectives to be achieved on each subject / basic competence are of course different (Khabibah et al., 2018; Druckman \& Ebner, 2017). In connection with these problems, efforts to improve the quality of the teaching and learning process of the English Teacher training class at Madrasah Aliyah level is a very urgent need to be done. One learning model that is thought to be able to bridge the gap is the discovery learning model (Syarif et al., 2020; Safaruddin et al., 2020; Rahman, 2017; Ellizar et al., 2018).

Learning English at Madrasah Aliyah is targeted that students can reach the functional level, namely communicating orally and writing English to solve daily problems. Discovery learning targets students to achieve this functional level. Discovery learning begins or departs from certain problems or issues that must be solved. Minister of Education and Culture Regulation No. 22 of 2016 concerning Basic and Secondary Education Process Standards states, discovery learning is "a learning model which produces discovery-based work". The background of using discovery learning is the demand for skills that must be mastered by students in the learning process. According to the regulation, skills are acquired through a series of activities or processes. The process is stimulation, problem statement / problem identification, data collection, data processing, verification, generalization. All learning activities must teach participants to be involved in the process of observation up to creation. It embodies discovery learning (Putri et al., 2020; Yerizon et al., 2018; Sulfemi, 2019).

Within the framework of this globalization, the field of education and training is required to meet the needs of training participants. One form of change that is demanded from instructor or widyaiswara is that widyaiswara must always update its professional skills. Among the student skills that always need to be improved are teaching skills (Wiriaatmadja, 2012). Widyaiswara's proficiency in teaching in the classroom will certainly affect the learning process and the learning outcomes of the training participants. To achieve this goal, the English learning process must be able to increase the involvement of the participants, so that it can be predicted that with the active and creative involvement of the participants it will also improve the quality of their learning outcomes. If participants are not active in learning activities, their knowledge and understanding of the teaching-learning process will be lacking, but on the other hand, it can be assumed that they will also have high language skills if they are taught by widyaiswara using various learning models, especially discovery learning. Discovery learning, according to Glynn and Anna K. Scott from the University of Georgia (2007) is "an approach / perspective to teaching and learning that recognize and addresses the situated nature of knowledge". In this definition, it is argued that discovery learning is learning that is associated with participants' knowledge in real life situations (Prasasti et al., 2019; Jayanto \& Noer, 2017).

If the learning material for writing descriptive texts is not creatively taught by widyaiswara, by not using a variety of methods or models, the training participants will quickly feel bored. According to Liswati (2017) "participants behave badly because learning is boring". To create such learning conditions, widyaiswara must have adequate knowledge and skills in selecting and implementing learning methods, strategies and models. He must be able to increase the potential for academic abilities and learning skills of training participants by providing encouragement for their psychological, academic and social development optimally. 
Based on empirical analysis, it turns out that there are still many widyaiswara who do not have sufficient knowledge and skills to select and apply various learning methods or models that are able to increase the excitement, activeness, creativity, and learning motivation of training participants. In addition, it is common for participants to have difficulty in capturing the contents of the messages conveyed by widyaiswara during the learning process, because the method used is not in line with the characteristics of the training material. The teaching and learning process should be able to take place in a conducive manner, and be able to facilitate training participants to conduct inquiries of the material being taught. This is important to do by widyaiswara, considering that learning delivered in a "dry" manner can kill the enthusiasm and interest in learning of the Training Participants (Liswati, 2017). Widyaiswara should be able to select and use a learning model related to the objectives to be achieved and meet the expectations of the training participants. In this study the authors tried to examine the effectiveness of the discovery learning model with the title "The Effectiveness of the Discovery Learning Model in Writing Descriptive Texts".

Recently there has been a series of research interests regarding discovery learning models. Discovery learning is effective in improving students" abilities in learning descriptive text writing skills (Sobari, \& Hanussalam, 2019; Mukharomah, 2015; Ariyana et al., 2020). The application of discovery learning models can improve listening learning outcomes and students' social attitudes (Hanafi, 2016), and Discovery Learning implementation is an appropriate method for teaching speaking for junior high school students and high school students (Krisnawati, 2015; Irmayanti, 2015). Discovery learning model is also an effective model for improving students' mathematics learning outcomes (Yurniwati, \& Hanum, L. 2017).

While existing studies have determined the effectiveness of discovery learning in improving learning outcomes clearly in madrasah / schools for students, the study has not yet addressed its effectiveness for training participants of education and training field. This research is focused on developing and understanding English teachers as training participants in Surabaya training center about writing descriptive text, and tracing the supporting factors and constraints in implementing discovery learning models in Madrasah Aliyah. This study aims to describe the effectiveness of the application of discovery learning models in writing descriptive texts.

\section{RESEARCH METHOD}

\section{General Background}

The design used in this study is a quasi-experimental, with two variables, the independent variable and the dependent variable. The independent variable in this study is learning English about writing descriptive texts both using discovery learning models and using conventional models. Meanwhile, the dependent variable is the participant's learning outcome which includes mastery of concepts and inquiry. The type of quasiexperimental design that the researchers used in this study was the Non-equivalent (Pretest and Posttest) Control-Group Design (Creswell, 1994). 
$\mathrm{O}=$ pre test and post test

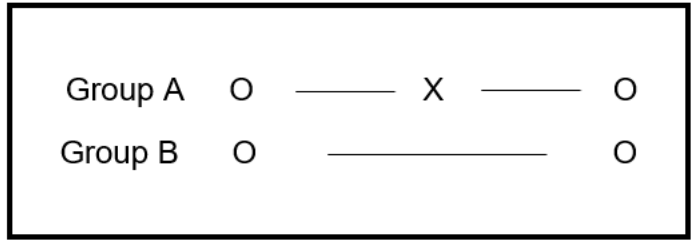

Figure 1. Research design.

$\mathrm{X}=$ teaching treatment with discovery learning model

A is the experimental class, and B is the control class, taken using a cluster sampling technique. Both groups received pretest and posttest, and only the experimental group received treatment. So, the experiment was carried out with two sample groups, namely the experimental class and the control class. The experimental class is a class that gets learning with a discovery learning model. While the control class is a class that follows conventional learning models. The conventional model is a model in which is characterized by a learning process dominated by widyaiswara, starting from opening learning activities, whilst activities in the form of widyaiswara explaining or providing information by lecturing, giving illustrations or examples, then participants asking questions, until finally widyaiswara feel that what he has taught can be understood by the training participants.

\section{Instrument and Procedures}

The research instrument used 4 instruments, namely the learning outcome test questions, the observation format during the learning process, interviews and questionnaires about the participants' views on learning using the Discovery Learning model provided. The experimental steps taken were as follows: 1) Determining the control class and the experimental class. By using the cluster sampling technique, the Madrasah Aliyah class I English teacher training class for class I was obtained as the control class and the MA class II English Teacher training class as the experiment class. 2) Conducting a pre test (T1) for the experimental class (Ec) to get T1.E, and against the control class (Cc) to get T1.C. 3) Conducting experiments on the experimental class (Ec), which provides learning to write descriptive texts with discovery learning models, (X). 4) For the control class (Cc), learning is carried out with the same material, tools, widyaiswara, and time as used in the experimental class (Ec), but the learning model used in the control class (Cc) is carried out with the one used in the experimental class (Ec) is not the same, in this study the model used in the control class (Cc) is the conventional model. 6) Conduct a post test (T2) both in the experimental group (Ec) to get T2.E, and in the control group (Cc) to get T2.C. 7) Calculating the average difference between T1 and T2, both for Ec and for Cc, using the statistical method of the SPSS version 11 technique. 8) Calculating the average difference between T2.E and T2.C to find out which approach is more effective, by performing a significance test of the average difference between T2.E and T2.C. The flow of the research implementation can be seen in the following Figure 2. 


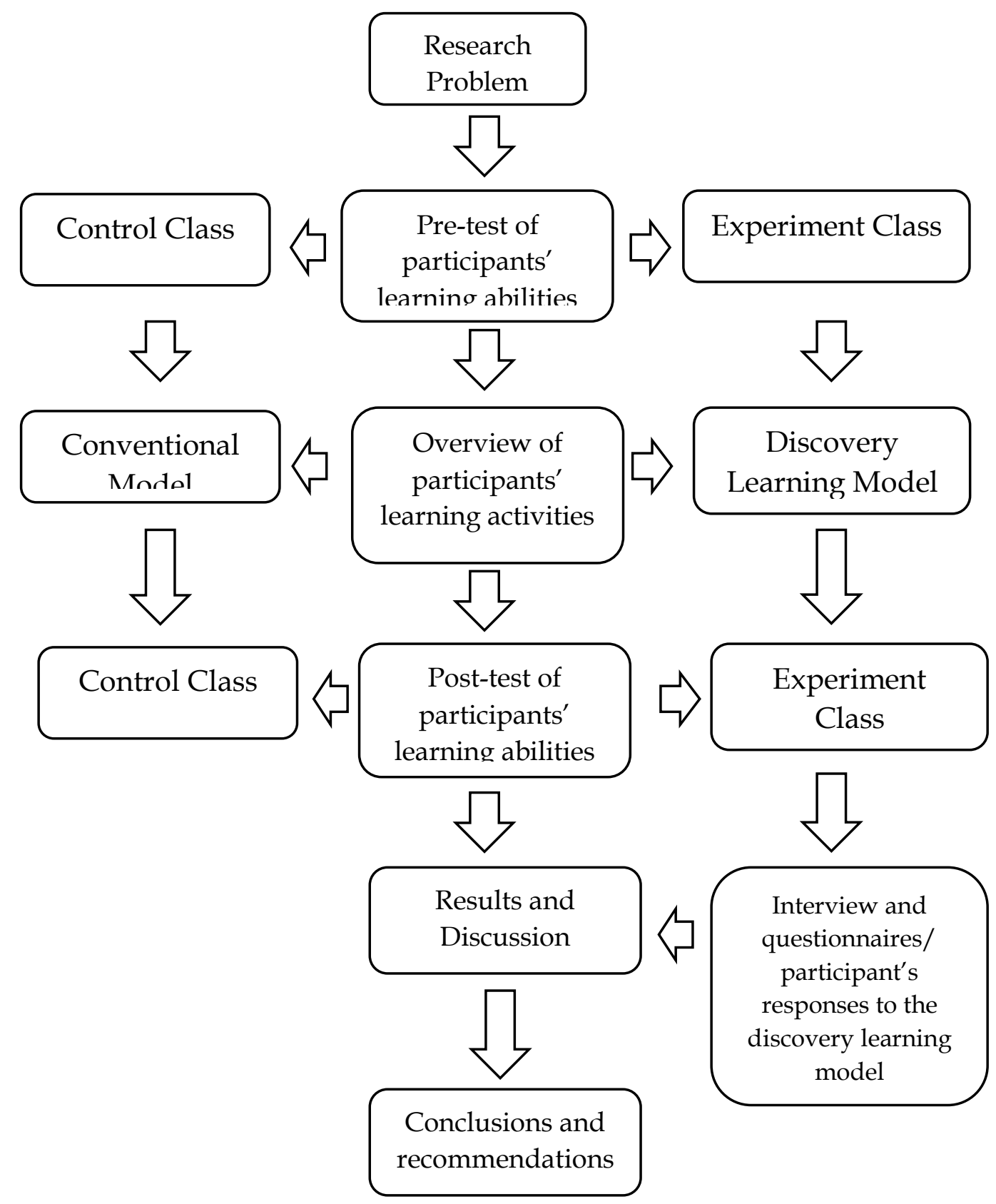

Figure 2. Research steps.

This research was conducted at the Surabaya Religious Education and Training Center. The process of learning English writing descriptive texts was carried out by English Widyaiswara who teaches at Surabaya Religious Education and Training Center who also acts as a researcher (observer).

\section{Sample and Population}

The population in this study were participants of the English teacher training in East Java, which consisted of Public Madrasah Aliyah and Private Madrasah Aliyah English teachers spread across 38 cities and districts. Two classes of samples were taken using cluster sampling technique. The number of sample members taken from the population was 60 training participants consisting of two classes, namely the control class with 30 students and the experimental class with 30 training participants. 


\section{Data Analysis}

This research is focused on two variables, namely: 1) Discovery learning model as the independent variable, 2) The learning outcomes of the training participants which include concept mastery and inquiry as the dependent variable. The test question sheet used is to measure participant learning outcomes in the form of products (values). The test used in this study is a subjective test in the form of an essay test that requires participants to remember, understand, and organize their ideas or things they have learned, by expressing or expressing these ideas in the form of a written description using their own words. This tool can assess various types of abilities, for example expressing opinions, thinking logically, and concluding. This research also considers the performance aspects of the participants during the learning process, through authentic assessment. The assessment is an assessment carried out during the learning process on the aspects of the skills (performance) that the participants acquire. In the authentic assessment what is seen is "Did the participants learn?", not "what has the participants already known". Authentic assessment is one of the characteristics of discovery learning models. One form of assessment of participant learning outcomes in the new Curriculum.

Participants' activities that were observed during the learning process included: 1 . Inquiry ability, which consists of: (a) finding learning resources / materials (b) the ability to obtain facts / information obtained. 2. Academic skills, which consist of: (a) mastery of the material / problem (b) the concordance of the flow of thinking (c) conformity to the material / problem. 3. Social skills, which consist of (a) activeness (b) the ability to respect the opinions of friends (c) the ability to give opportunities to others. To determine the effectiveness of the discovery learning model in learning English on the basic competence of writing descriptive texts, quantitative analysis was carried out through $\mathrm{t}$ test statistics, with the Paired Sample t Test analysis technique using SPSS. The t-test was done by comparing the test results (pre test and post test) between the experimental class and the control class. Based on the measurement results through this t-test statistic, it can be seen that the average difference in test results between the experimental class and the control class shows the effectiveness of the discovery learning model in learning English, on the basic competence of writing descriptive text. While the analysis of the data obtained from learning outcomes in the sense that the process is carried out based on authentic assessment or performance assessment, is carried out continuously throughout the learning process, from the first meeting to the last meeting, using a process assessment sheet (observation sheet).

\section{RESULTS AND DISCUSSION}

After processing the data using the SPSS version 11 technique, the pretest results in the experimental class and control class can be obtained, after analyzing the two groups, the highest value, lowest value, average value, and standard deviation are obtained in full in Table 1.

Table 1. Highest value, lowest value, average value, and standard deviation pretest of concepts mastery and inquiry ability.

\begin{tabular}{lcccccccccc}
\hline \multirow{2}{*}{\multicolumn{1}{c}{ Aspect }} & Max & \multicolumn{4}{c}{ Experiment Class } & \multicolumn{4}{c}{ Control Class } \\
\cline { 3 - 11 } & Value & $x_{\min }$ & $x_{\text {maks }}$ & $\bar{x}$ & sd & $x_{\text {min }}$ & $x_{\text {maks }}$ & $\bar{x}$ & sd \\
\hline Concept & 6,0 & 1,4 & 3,8 & 2,32 & 0,6157 & 1,4 & 3,9 & 2,5 & 0,6664 \\
Understanding & 6,0 & & & & & & & & \\
\hline Inquiry Ability & 4,0 & 0,4 & 2,5 & 1,21 & 0,5054 & 0,4 & 1,8 & 1,2 & 0,3751 \\
\hline
\end{tabular}


The Effectiveness of Discovery Learning Model in Writing Descriptive Text

\begin{tabular}{lcccccccccc}
\hline \multirow{2}{*}{ Aspect } & Max & \multicolumn{4}{c}{ Experiment Class } & \multicolumn{4}{c}{ Control Class } \\
\cline { 3 - 10 } & Value & $x_{\text {min }}$ & $x_{\text {maks }}$ & $\bar{x}$ & sd & $x_{\text {min }}$ & $x_{\text {maks }}$ & $\bar{x}$ & sd \\
\hline $\begin{array}{l}\text { Overall participant } \\
\text { abilities }\end{array}$ & 10,0 & 2,0 & 6,0 & 3,6 & 1,0233 & 2,0 & 6,0 & 3,7 & 0,9791 \\
\hline
\end{tabular}

From Table 1, it can be seen that the pretest average score of the two classes is not significantly different in both understanding and inquiry abilities in learning to write descriptive texts. The mean scores of concept understanding and inquiry abilities in the experimental class were 2.32 and 1.21, respectively, and the overall average ability of the training participants in the experimental class was 3.6. Meanwhile, the average value of concept understanding and inquiry ability in the control class was 2.50 and 1.20, respectively, and the overall average ability of the participants in the control class was 3.70. The normality test is carried out on three aspects, namely, the ability to master concepts, the ability of inquiry and the overall ability of the participants in the learning process of writing descriptive texts. The results of the calculation of the normality test for these three aspects for the control and experimental classes are presented in Table 2.

Table 2. Pretest normality test results for experimental and control class.

\begin{tabular}{lcccccccc}
\hline \multirow{2}{*}{ Aspect } & \multicolumn{4}{c}{ Experiment Class } & \multicolumn{4}{c}{ Control Class } \\
\cline { 2 - 8 } & $\mathbf{d k}$ & $\chi^{2}$ count & $\chi^{2}$ Table & Conclusion & $\mathbf{d k}$ & $\chi^{2}$ count & $\chi^{2}$ Table & Conclusion \\
\hline $\begin{array}{l}\text { Concept } \\
\text { Understanding }\end{array}$ & 15 & 12,667 & 25,00 & Normal & 16 & 6,267 & 26,30 & Normal \\
\hline $\begin{array}{l}\text { Inquiry } \\
\text { Ability }\end{array}$ & 15 & 9,467 & 25,00 & Normal & 12 & 6.400 & 21,03 & Normal \\
\hline $\begin{array}{l}\text { Overall } \\
\text { participant } \\
\text { abilities }\end{array}$ & 8 & 10,200 & 15,51 & Normal & 7 & 10,000 & 14,07 & Normal \\
\hline
\end{tabular}

Notes:

$\mathrm{dk}$ : degrees of freedom

From Table 2, it can be seen that $\chi_{\text {hitung }}^{2} \leq \chi_{\text {tabel }}^{2}$ in both classes (experimental and control class), both the ability to understand concepts, the ability of inquiry and the ability of the participants as a whole. Thus it can be concluded that the pretest scores for the experimental and control classes on these three aspects are normally distributed. Furthermore, the variance homogeneity test was carried out on the pretest value of the two classes (experimental and control classes) at the significance level $\alpha=0.05$ with the test criteria: if $\mathrm{F}_{\text {hitung }} \leq \mathrm{F}_{\text {tabel }}$ then it is concluded that the variance of the two classes is homogeneous, whereas if $F_{\text {hitung }} \leq \mathrm{F}_{\text {tabel }}$ it is concluded that the variance of the two classes is not homogeneous. The results of the homogeneity calculation are presented in Table 3.

Table 3. Pretest Homogeneity Test Results for Experimental and Control Class

\begin{tabular}{|c|c|c|c|c|c|}
\hline \multirow[b]{2}{*}{ Aspect } & \multicolumn{2}{|c|}{ Variance } & \multirow[b]{2}{*}{$F_{\text {count }}$} & \multirow[b]{2}{*}{$\mathbf{F}_{\text {Table }}$} & \multirow[b]{2}{*}{ Conclusion } \\
\hline & Experiment Class & Control Class & & & \\
\hline Concept Understanding & 0,3791 & 0,4441 & 1,1715 & 2,450 & Homogen \\
\hline Inquiry Ability & 0,2554 & 0,1410 & 1,811 & 2,450 & Homogen \\
\hline $\begin{array}{l}\text { Overall participant } \\
\text { abilities }\end{array}$ & 1,0471 & 0,9586 & 1,0923 & 2,450 & Homogen \\
\hline
\end{tabular}


Furthermore, testing the mean difference in pretest results using the t-test at the significance level $\alpha=0.05$ (two-party test, $1 / 2 \alpha=0.025$ ) with the testing criteria: H0 is accepted if $-\mathrm{t}_{\text {tabel }}<\mathrm{t}_{\text {hitung }}<+\mathrm{t}_{\text {tabel }}$, while in other circumstances $\mathrm{H} 0$ is rejected.

Table 4. Pretest Class Difference Test Experiment and Control Class

\begin{tabular}{|c|c|c|c|c|c|c|c|c|c|}
\hline \multirow[b]{2}{*}{ Aspect } & \multicolumn{3}{|c|}{ Experiment Class } & \multicolumn{3}{|c|}{ Control Class } & \multirow[b]{2}{*}{$t_{\text {count }}$} & \multirow[b]{2}{*}{$\mathbf{t}_{\text {Table }}$} & \multirow[b]{2}{*}{ Conclusion } \\
\hline & $\overline{x_{e}}$ & $\mathrm{~s}_{\mathrm{e}}$ & $\mathbf{S e}^{2}$ & $\overline{x_{k}}$ & $\mathbf{s}_{\mathbf{k}}$ & $s_{k}^{2}$ & & & \\
\hline $\begin{array}{l}\text { Concept } \\
\text { Understanding }\end{array}$ & 2,323 & 0,616 & 0,379 & 2,500 & 0,666 & 0,444 & 1,073 & 1,672 & No difference \\
\hline Inquiry Ability & 1,210 & 0,505 & 0,255 & 1,200 & 0,375 & 0,141 & 0,087 & 1,672 & No difference \\
\hline $\begin{array}{l}\text { Overall } \\
\text { participant } \\
\text { abilities }\end{array}$ & 3,600 & 1,023 & 1,047 & 3,700 & 0,979 & 0,958 & 0,388 & 1,672 & No difference \\
\hline
\end{tabular}

Based on Table 4. obtained:

Concept Understanding, because $t$ count $=1.073$ is in the interval -1.672 to +1.672 ( $t$ Table $<t$ count $<+t$ Table), it can be concluded that the understanding of the concepts of the participants of the two classes (experimental and control class) is relatively the same or there is no significant difference.

Inquiry ability, because $t$ count $=0.087$ is in the interval -1.672 to +1.672 ( $t$ Table $<t$ count $<+\mathrm{t}$ Table), it can be concluded that the participants' inquiry abilities of both classes (experimental and control class) are relatively the same or there is no significant difference.

Overall participant abilities, because $t$ count $=-0.388$ is in the interval -1.672 to $+1.672(t$ Table $<\mathrm{t}$ count $<+\mathrm{t}$ Table), it can be concluded that the overall ability of the participants in both classes (experimental and control class) is relatively the same or there is no significant difference.

Based on the posttest scores of the control and experimental classes, after processing the values obtained the lowest value $(X \min )$, highest value $(X \max )$, average value ( $X$ average) and standard deviation (s) for the experimental and control classes as shown in Table 5 .

Table 5. Highest value, lowest value, average value, and standard deviation posttest of mastery of concepts and inquiry ability.

\begin{tabular}{lccccccccc}
\hline \multirow{2}{*}{ Aspect } & Max & \multicolumn{4}{c}{ Experiment Class } & \multicolumn{4}{c}{ Control Class } \\
\cline { 3 - 9 } & Value & $x_{\min }$ & $x_{\text {maks }}$ & $\bar{x}$ & sd & $x_{\min }$ & $x_{\text {maks }}$ & $\bar{x}$ & sd \\
\hline $\begin{array}{l}\text { Concept } \\
\text { Understanding }\end{array}$ & 6,0 & 3,6 & 5,2 & 4,27 & 0,4856 & 2,2 & 4,7 & 3,4 & 0,5585 \\
\hline $\begin{array}{l}\text { Inquiry Ability } \\
\text { 4,0 }\end{array}$ & 2,5 & 4,8 & 3,10 & 0,4860 & 1,3 & 3,5 & 2,2 & 0,5818 \\
\hline $\begin{array}{l}\text { Overall } \\
\text { participant } \\
\text { abilities }\end{array}$ & 10,0 & 6,5 & 9,0 & 7,40 & 0,7589 & 4,0 & 7,0 & 5,63 & 0,8503 \\
\hline
\end{tabular}

Based on normality testing using the chi-square test $\left(\chi^{2}\right)$ at a significance level of $\alpha$ $=0.05$ on concept understanding, inquiry abilities and the overall ability of participants in learning to write descriptive texts. The conclusion is that the post-test scores are 
normally distributed. The summary results of the data normality test using the chi-square statistical test can be seen in Table 6 .

Table 6. Posttest normality test for experiment and control class.

\begin{tabular}{lcccccccc}
\hline & \multicolumn{4}{c}{ Experiment Class } & \multicolumn{4}{c}{ Control Class } \\
\cline { 2 - 8 } Aspect & $\mathbf{d k}$ & $\chi^{2}$ count & $\chi^{2}$ Table & Conlusion & $\mathbf{d k}$ & $\chi^{2}$ count & $\chi_{2}$ & Conlusion \\
\hline $\begin{array}{l}\text { Concept } \\
\text { Understanding }\end{array}$ & 12 & 13,333 & 21,03 & Normal & 16 & 10,800 & 26,30 & Normal \\
\hline Inquiry Ability & 13 & 22,267 & 22,36 & Normal & 16 & 7,400 & 26,30 & Normal \\
\hline $\begin{array}{l}\text { Overall } \\
\text { participant } \\
\text { abilities }\end{array}$ & 5 & 12,800 & 15,09 & Normal & 6 & 5,467 & 11,07 & Normal \\
\hline
\end{tabular}

\section{Notes:}

$\mathrm{dk}$ : degrees of freedom

The data is concluded to be normally distributed if $\chi^{2}$ count $\leq \chi^{2}$ Table.

The data in Table 6. above shows that the conceptual understanding, inquiry abilities and overall abilities of participants are normally distributed, then proceed with testing the variance homogeneity of the control class and the experimental class on concept understanding, inquiry abilities and the overall ability of participants in learning writing descriptive text with a significance level of $\alpha=0.05$ is presented in Table 7 .

Table 7. Posttest homogeneity test results for experimental and control class.

\begin{tabular}{|c|c|c|c|c|c|}
\hline \multirow{2}{*}{ Aspect } & \multicolumn{2}{|c|}{ Variance } & \multirow{2}{*}{$F_{\text {count }}$} & \multirow{2}{*}{$\mathbf{F}_{\text {Table }}$} & \multirow{2}{*}{$\begin{array}{c}\text { Conlusio } \\
n\end{array}$} \\
\hline & Experiment Class & Control Class & & & \\
\hline $\begin{array}{l}\text { Concept } \\
\text { Understanding }\end{array}$ & 0,2358 & 0,3119 & 1,3227 & 2,450 & $\begin{array}{c}\text { Homoge } \\
n\end{array}$ \\
\hline Inquiry Ability & 0,2362 & 0,3385 & 1,4331 & 2,450 & $\begin{array}{c}\text { Homoge } \\
n\end{array}$ \\
\hline $\begin{array}{l}\text { Overall } \\
\text { participant } \\
\text { abilities }\end{array}$ & 0,5759 & 07230 & 1,2554 & 2,450 & $\begin{array}{c}\text { Homoge } \\
n\end{array}$ \\
\hline
\end{tabular}

Table 7. shows that the variance of concept understanding, inquiry ability and overall participant ability in learning to write descriptive text are the same (homogeneous). Furthermore, testing the difference in the average post-test result data on concept understanding, inquiry ability and overall participants' abilities using the ttest at the significance level $\alpha=0.05$ (two-party test, $1 / 2 \alpha=0.025$ ) with the test criteria: $\mathrm{HO}$ is accepted if $-\mathrm{t}_{\text {tabel }}<\mathrm{t}_{\text {hitung }}<+\mathrm{t}_{\text {tabel }}$, while in other circumstances H0 is rejected. Hypothesis 1 proposed in this study is "the ability to master the concept of participants who learn with discovery learning models is higher than the ability of participants who learn with conventional models". Based on the research hypothesis proposed, the null hypothesis (H0) being tested is as follows: H0: there is no difference in the concept mastery ability of participants who learn using discovery learning models with those who learn using conventional models. 
Table 8. List of concept mastery t count.

\begin{tabular}{|c|c|c|c|c|c|c|c|c|}
\hline & \multicolumn{5}{|c|}{ Paired Diffrences } & \multirow{3}{*}{$\mathbf{t}$} & \multirow{3}{*}{ df } & \multirow{3}{*}{ Sig } \\
\hline & \multirow[t]{2}{*}{ Mean } & \multirow[t]{2}{*}{$\begin{array}{c}\text { Std. } \\
\text { Deviation }\end{array}$} & \multirow{2}{*}{$\begin{array}{c}\text { Std. } \\
\text { Error } \\
\text { Mean }\end{array}$} & \multicolumn{2}{|c|}{$\begin{array}{l}95 \% \text { Confidence } \\
\text { Interval of the } \\
\text { Diffrence }\end{array}$} & & & \\
\hline & & & & Lower & Upper & & & \\
\hline $\begin{array}{l}\text { Pair } 1 \\
\text { Posteskt- } \\
\text { Postes }\end{array}$ & -.797 & .8434 & .1540 & -1.112 & -.482 & -5.174 & 29 & .000 \\
\hline
\end{tabular}

From the calculation of the average difference using the $\mathrm{t}$ test at $\alpha=0.05$, $\mathrm{df} 29$ (in Table 8 . above), it is obtained $t$ count $=-5.174$, while $t$ Table $=1.699$. Because it uses a two-party test, the area of acceptance is $-\mathrm{t}$ Table $\leq \mathrm{t}$ count $\leq \mathrm{t}$ Table, meanwhile $\mathrm{t}$ count $<$ $\mathrm{t}$ Table, therefore $\mathrm{HO}$ is rejected. This means that the concept mastery ability of participants who learn with discovery learning models is higher when compared to participants who learn with conventional models.

Hypothesis 2 proposed in this study is "the ability of participants who learn with discovery learning model is higher than the ability of participants who learn with conventional models".

Table 9. List $t$ count inquiry ability.

\begin{tabular}{|c|c|c|c|c|c|c|c|c|}
\hline & \multicolumn{5}{|c|}{ Paired Diffrences } & \multirow{3}{*}{$\mathbf{t}$} & \multirow{3}{*}{ df } & \multirow{3}{*}{ Sig } \\
\hline & \multirow[t]{2}{*}{ Mean } & \multirow[t]{2}{*}{$\begin{array}{c}\text { Std. } \\
\text { Deviation }\end{array}$} & \multirow{2}{*}{$\begin{array}{l}\text { Std. } \\
\text { Error } \\
\text { Mean }\end{array}$} & \multicolumn{2}{|c|}{$\begin{array}{l}95 \% \text { Confidence } \\
\text { Interval of the } \\
\text { Diffrence }\end{array}$} & & & \\
\hline & & & & Lower & Upper & & & \\
\hline Pair 1 & & & & & & & & \\
\hline $\begin{array}{c}\text { Posteskt- } \\
\text { Postes }\end{array}$ & -.673 & .7538 & .1376 & -.955 & -.392 & -4.892 & 29 & .000 \\
\hline
\end{tabular}

From the calculation of the average difference using the $\mathrm{t}$ test at $\alpha=0.05$, df 29 (Table 4.5 above), the obtained $\mathrm{t}$ count $=-4.892$ while $\mathrm{t}$ Table $=1.699$. Because it uses a two party test, the area of acceptance is $-t$ Table $\leq t$ count $\leq t$ Table, meanwhile $t$ count $<t$ Table, therefore $\mathrm{H} 0$ is rejected. This means that the inquiry ability of participants who learn with discovery learning models is higher when compared to participants who learn with conventional models. Hypothesis 3 proposed in this study is "The ability to master concepts and inquiry abilities (as a whole) of participants who learn using discovery learning models are higher than the abilities of participants who learn with conventional models".

Table 10. List $t$ count.

\begin{tabular}{|c|c|c|c|c|c|c|c|c|}
\hline & \multicolumn{5}{|c|}{ Paired Diffrences } & \multirow{3}{*}{$\mathbf{t}$} & \multirow{3}{*}{ df } & \multirow{3}{*}{ Sig } \\
\hline & \multirow[t]{2}{*}{ Mean } & \multirow[t]{2}{*}{$\begin{array}{c}\text { Std. } \\
\text { Deviation }\end{array}$} & \multirow{2}{*}{$\begin{array}{l}\text { Std. } \\
\text { Error } \\
\text { Mean }\end{array}$} & \multicolumn{2}{|c|}{$\begin{array}{l}\text { 95\% Confidence } \\
\text { Interval of the } \\
\text { Diffrence }\end{array}$} & & & \\
\hline & & & & Lower & Upper & & & \\
\hline $\begin{array}{c}\text { Pair } 1 \\
\text { Posteskt- } \\
\text { Postes }\end{array}$ & -1.767 & 1.1502 & .2100 & .2100 & -2.196 & -8.413 & 29 & .000 \\
\hline
\end{tabular}


After calculating the average difference using the $\mathrm{t}$ test at $\alpha=0.05$, df 29 (in Table 10 . above), the obtained $t$ count $=-8.413$ while $t$ Table $=1.699$. Because it uses a two-party test, the area of acceptance is $-t$ Table $\leq t$ count $\leq t$ Table, meanwhile $t$ count $<t$ Table, therefore $\mathrm{HO}$ is rejected. This means that the concept mastery and inquiry abilities of participants (a combination of the two) who learn using the discovery learning model are better than the abilities of participants who learn conventionally. Overall the results of the calculation of the average difference test post-test concept understanding, inquiry abilities and the overall ability of participants are presented in Table 11.

Table 11. Test for difference in the mean class posttest experiment and control class.

\begin{tabular}{|c|c|c|c|c|c|c|c|c|c|}
\hline \multirow{2}{*}{ Aspect } & \multicolumn{3}{|c|}{ Experiment Class } & \multicolumn{3}{|c|}{ Control Class } & \multirow{2}{*}{$t_{\text {hitung }}$} & \multirow{2}{*}{$\mathrm{t}_{\text {tabel }}$} & \multirow{2}{*}{ Conclusion } \\
\hline & $\overline{x_{e}}$ & $\mathrm{se}_{\mathrm{e}}$ & $\mathrm{Se}^{2}$ & $\overline{x_{k}}$ & $\mathrm{~S}_{\mathrm{k}}$ & $\mathrm{Sk}^{2}$ & & & \\
\hline $\begin{array}{l}\text { Concept } \\
\text { Understanding }\end{array}$ & 4,270 & 0,486 & 0,236 & 3.400 & 0,559 & 0,312 & 6,444 & 1,672 & $\begin{array}{l}\text { Significantly } \\
\text { different at } p \\
=0.05\end{array}$ \\
\hline Inquiry Ability & 3,100 & 0,486 & 0,236 & 2,200 & 0,582 & 0,339 & 6,522 & 1,672 & $\begin{array}{l}\text { Significantly } \\
\text { different at } p \\
=0.05\end{array}$ \\
\hline $\begin{array}{l}\text { Overall } \\
\text { participant } \\
\text { abilities }\end{array}$ & 7,400 & 0,759 & 0,576 & 5,630 & 0,850 & 0,723 & 8,509 & 1,672 & $\begin{array}{l}\text { Significantly } \\
\text { different at } p \\
=0.05\end{array}$ \\
\hline
\end{tabular}

To see the increase in participants 'understanding of the concept, the participants' inquiry abilities and the overall ability of participants in learning to write descriptive text, between participants who received learning using the discovery learning model and participants who received learning with the conventional model was to calculate the gain of the two groups using the normalized gain formula. The results of the complete normalized gain calculation are presented in Table 12.

Table 12. Normalized gain experiment and control class.

\begin{tabular}{|c|c|c|c|c|}
\hline \multirow[b]{2}{*}{ Aspect } & \multicolumn{2}{|c|}{ Experiment Class } & \multicolumn{2}{|c|}{ Control Class } \\
\hline & $\begin{array}{c}\text { Average } \\
\text { Normalized Gain }\end{array}$ & Category & $\begin{array}{c}\text { Average } \\
\text { Normalized Gain }\end{array}$ & Category \\
\hline Concept Understanding & 0,252 & Low & 0.112 & Low \\
\hline Inquiry Ability & 0.215 & Moderate & 0.119 & Low \\
\hline $\begin{array}{l}\text { Overall participant } \\
\text { abilities }\end{array}$ & 0.603 & Moderate & 0.305 & Moderate \\
\hline
\end{tabular}

From Table 12, it can be seen that the normalized gain in understanding the concept, the ability of inquiry and the overall ability of the participants in the experimental class is greater than the control class, but the gain for both classes is in the low category. Furthermore, to see whether the normalized gain of the experimental class was higher than the control class, a t-test was carried out at the significance level $\alpha=0.05$ (two-party test, $1 / 2 \alpha=0.025)$. Before using the average difference test with the t-test on the gain of the two classes, the gain of the two classes must meet the assumptions of normality and homogeneity. Based on normality testing using the chi-square test $\left(\chi^{2}\right)$ at a significance level of $\alpha=0.05$ on concept understanding, inquiry abilities and the overall ability of participants, it is concluded that the normalized gain scores for the control class and experimental class are normally distributed. The summary results of the normality test 
on the normalized gain score using the chi-square statistical test in the experimental class and control class can be seen in Table 13.

Table 13. Results of normalized gain score normality test for experiment and control class.

\begin{tabular}{lccccccccc}
\hline & \multicolumn{4}{c}{ Experiment Class } & \multicolumn{5}{c}{ Control Class } \\
\cline { 2 - 8 } Aspect & $\mathbf{d k}$ & $\mathbf{X}^{\mathbf{2}}$ count & $\chi^{2}$ Table & Conclusion & $\mathbf{d k}$ & $\mathbf{X}^{2}$ count & $\begin{array}{c}\chi^{2} \\
\text { Table }\end{array}$ & Conclusion \\
\hline $\begin{array}{l}\text { Concept } \\
\text { Understanding }\end{array}$ & 22 & 3,733 & 33,92 & Normal & 28 & 0,933 & 41,34 & Normal \\
\hline $\begin{array}{l}\text { Inquiry } \\
\text { Ability }\end{array}$ & 25 & 2,933 & 37,65 & Normal & 27 & 1,733 & 40,11 & Normal \\
\hline $\begin{array}{l}\text { Overall } \\
\text { participant } \\
\text { abilities }\end{array}$ & 15 & 6,267 & 25,00 & Normal & 19 & 10.000 & 30,14 & Normal \\
\hline
\end{tabular}

Notes:

$\mathrm{dk}$ : degrees of freedom

The data is concluded to be normally distributed if $\mathbf{X}^{2}$ count $\leq \mathbf{X}^{2}$ Table

After the normalized gain score is normally distributed, then proceed with testing the suitability (homogeneity) of the variance against the control class and the experimental class on understanding, inquiry ability and the ability of the participants as a whole, with a significance level $\alpha=0.05$. The results of the calculation of the normalized gain score data homogeneity are presented in the Table 14.

Table 14. Homogeneity test of normalized gain experiment and control class.

\begin{tabular}{llllll}
\hline \multirow{2}{*}{ Aspect } & \multicolumn{2}{c}{ Varianc } & \multirow{2}{*}{$\mathbf{F}_{\text {Count }}$} & \multirow{2}{*}{$\mathbf{F}_{\text {Table }}$} & \multirow{2}{*}{ Conclusion } \\
\cline { 2 - 5 } & \multicolumn{2}{c}{ Experiment Class } & Control Class & & \\
\hline Concept Understanding & 0,003 & 0,006 & 2,00 & 2,450 & Homogen \\
\hline Inquiry Ability & 0,002 & 0,004 & 2.00 & 2,450 & Homogen \\
\hline $\begin{array}{l}\text { Overall participant } \\
\text { abilities }\end{array}$ & 0,007 & 0,009 & 1,286 & 2,450 & Homogen \\
\hline
\end{tabular}

Table 14. shows that the normalized gain variance in understanding the concept, inquiry ability and the ability of the participants as a whole, in both classes are the same (homogeneous). Furthermore, testing the difference in the average normalized gain data on concept understanding, inquiry abilities and the ability of the participants as a whole, using the t-test at the significance level $\alpha=0.05$ (two-party test, $1 / 2 \alpha=0.025$ ). The results of normalized gain calculations using the t-test are obtained:

The value of $t$ count for the gain of understanding the concept is 7.778 while the $t$ Table at the significance level $\alpha=0.05$ (two-party test, $1 / 2 \quad \alpha=0.025$ ) with degrees of freedom $\mathrm{dk}=30+30-2=58$ is 1.672 . Because $\mathrm{t}$ count $>\mathrm{t}$ Table ( $\mathrm{t}$ count is not at the interval (- $\mathrm{t}$ Table, $+\mathrm{t}$ Table)), it can be concluded that the gain of the experimental class is better than the control class or for participants who get learning with the discovery learning model. There is a significant increase in concept understanding than the participants who get learning with conventional models.

The value of $t$ count for the gain of inquiry ability is 6.667 , while the $t$ Table at the significance level $\alpha=0.05$ (two-party test, $1 / 2 \quad \alpha=0.025$ ) with degrees of freedom $\mathrm{dk}=$ $30+30-2=58$ is 1.672. Because $t$ count $>t$ Table ( $t$ count is not at the interval $(-t$ Table, 
$+t$ Table)), it can be concluded that the gain of the experimental class is better than the control class or in participants who get learning with the discovery learning model, there is a significant increase in the ability of the inquiry than the participants who get learning with conventional models.

The value of $t$ count for the overall gain of the overall ability of the participants ( $a$ combination of conceptual understanding with inquiry abilities) is 13,244 , while the $t$ Table at the significance level $\quad \alpha=0.05$ (two-party test, $1 / 2 \quad \alpha=0.025$ ) with degrees of freedom $d k=30+30-2=58$ is 1,672 . Because $t$ count $>t$ Table $(t$ count is not at the interval (- Table, $+\mathrm{t}$ Table)), it can be concluded that the gain of the experimental class is better than the control class or for participants who get learning with the discovery learning model. There is a significant increase in the ability of the participants as a whole. (combination of conceptual understanding with inquiry abilities) than participants who get learning with conventional models. In more detail, the results of the gain calculation using the t-test for both groups are presented in Table 15.

Table 15. Test for difference in the average normalized gain of the experiment class and control class.

\begin{tabular}{|c|c|c|c|c|c|c|c|c|c|c|}
\hline \multirow{2}{*}{ Aspect } & \multirow{2}{*}{ dk } & \multicolumn{3}{|c|}{ Experiment Class } & \multicolumn{3}{|c|}{ Control Class } & \multirow[b]{2}{*}{$\mathbf{t}_{\text {count }}$} & \multirow{2}{*}{$\mathbf{t}_{\text {Table }}$} & \multirow[b]{2}{*}{ Conclusion } \\
\hline & & $\overline{x_{e}}$ & $\mathbf{s}_{\mathrm{e}}$ & $\mathbf{S e}^{2}$ & $\overline{x_{k}}$ & $\mathbf{s}_{\mathrm{k}}$ & $\mathbf{s}_{\mathbf{k}^{2}}$ & & & \\
\hline $\begin{array}{l}\text { Concept } \\
\text { Understanding }\end{array}$ & 58 & 0.252 & 0.058 & 0.0034 & .112 & 0.078 & 0.0061 & 7.778 & 1.672 & $\begin{array}{l}\text { Significantly } \\
\text { different at } p= \\
0.05\end{array}$ \\
\hline Inquiry Ability & 58 & 0.215 & 0.039 & 0.0015 & .119 & 0.069 & 0.0048 & 6.667 & 1.672 & $\begin{array}{l}\text { Significantly } \\
\text { different at } \mathrm{p}= \\
0.05\end{array}$ \\
\hline $\begin{array}{l}\text { Overall } \\
\text { participant } \\
\text { abilities }\end{array}$ & 58 & 0.603 & 0.082 & 0.0067 & 1.305 & 0.092 & 0.0085 & 13.244 & 1.672 & $\begin{array}{l}\text { Significantly } \\
\text { different at } p= \\
0.05\end{array}$ \\
\hline
\end{tabular}

Observation of the activities of the participants during the learning process using the discovery learning model was carried out by the researcher using the observation sheet. In general, the implementation of learning with the discovery learning model is going well. At the beginning of learning, widyaiswara implemented apperception, by throwing several problems to determine the level of participants 'initial knowledge, then continued with discussions in their respective groups, in the group discussion the participants identified the problems, the relationship of the problems discussed with the participants' daily life or circumstances, then continued with a class discussion to find answers to problems, and write down the answers that resulted from the discussion results according to each language.

Several things that can be observed during the lesson are described as follows: First, the discovery learning model is a new learning model for participants and widyaiswara. Because of that at the first meeting and even at the second meeting the participants still looked stiff. Several participants admitted that they did not know what to do so that the stages of the discovery learning (reading / writing / seeking information) model and the group discussion stage did not run optimally. But at the next meeting the participants seemed more enthusiastic about the learning. They generally do not hesitate to express their opinions, so that class discussions become livelier and the learning atmosphere becomes more conducive. 
Second, the application of this discovery learning model, after the participants understand what they have to do, such as; in finding learning resources, information, conducting discussion activities to solve problems about descriptive texts, resulting in increased participant involvement in learning. This discovery learning model succeeded in creating a new atmosphere for the participants so that learning was more conducive, among others, it could increase the activity and creativity of the participants and increase the positive attitude of the participants towards learning to write descriptive texts. So far, learning English always starts from widyaiswara explaining, participants pay close attention and take notes, occasionally participants ask questions then widyaiswara answers, learning material is more in the form of factual things, rarely involves participants as learning subjects, and rarely connects with the real world around the participants, and the current situation. However, with this new approach, it is the participants who become the subject of learning.

Third, in terms of the learning process, the ability of inquiry that has been achieved by most of the participants from the second meeting to the fifth meeting has shown significant progress; participants diligently seek and read learning resources, dare to express opinions, able to cooperate, respect friends' opinions, encourage friends to speak up, take responsibility, respect time, can argue, and are good at leading discussions. In terms of knowledge acquisition (conceptual mastery) and analytical skills, participants can relate to current conditions, can link or provide examples with conditions in other areas (synchronous), can compile reports chronologically (diachronic), can analyze and conclude, and complete tasks on time.

Fourth, the learning atmosphere shows that the participants are excited and enjoy learning activities. This can be seen from the results of tests held at the last lesson hour of the sixth meeting, indicating an increase in the quality and product aspects of learning.

Based on the results of the interview, none of the participants said they were not happy with the discovery learning model. According to the participants this method of learning makes them active, not sleepy, doesn't feel like time is up, becomes courageous in expressing opinions, becomes compact, is motivated to master all material so they can answer friends' questions, tries to master all the material so that they can find problems to ask (means diligently reading). Others said that they liked it because it practiced debate, and it wasn't stressful.

Another form of response that emerged and put forward by the participants at the end of the implementation of the discovery learning model was that participants felt and gave an assessment that English widyaiswara was getting better, because it always provided motivation, guidance, served, and was democratic, therefore learning was not boring, on the contrary participants become more diligent and happier to learn English.

The learning process in the control class is carried out with a conventional approach. In this class, widyaiswara conducts learning activities as usual, first he checked the attendance of participants followed by apperception, then explain the material while the participants take notes, give examples, the participants listen carefully and if there are participants who are not clear ask questions. Questions answered by widyaiswara were once again thrown at the other participants. After this activity was finished, he continued to explain, occasionally gave examples, participants listened carefully and if there were participants who were not clear about asking questions, he answered questions, and occasionally he asked or asked other participants again, and so on until the lesson ended. 
From the overall test results (the combination of concept mastery and inquiry posttest results) it can be seen that the lowest pre-test score of the control class is 2.0 with the highest score of 6.0 on average 3.70, while the lowest post-test score in the control class is 4.0, the highest score is 70 and the average was 5.63. This means that in the control class, where the learning process with the conventional approach carried out by widyaiswara has been carried out so far, there is an increase in the average value of 1.97 . Whereas in the experimental class the lowest pre-test score obtained by participants was 2.0, the highest score was 60, average 3.57, but there was an increase in the acquisition of better learning outcomes, namely with the lowest post-test score of 6.5 the highest 9.0 average 7.40 , there was an increase in the average value of 2.83. Based on the results above, it can be seen that after the treatment of the two studies, the increase from the pre-test value to the post-test value. This is supported by research by Shellawati \& Sunarti (2018) which states that the increase in pre-test and post-test scores after giving inquiry learning treatment.

Then the research data above obtained the three hypotheses tested through the test, it was found that there was a significant difference in the average understanding of the concept and the ability of inquiry in the experimental group and the control group as well as the average ability of students as a whole. The average difference is between the ability of students in concept understanding and inquiry abilities, learning through discovery learning models with the abilities of students whose learning uses conventional models. In line with Gayatri et al (2017), there is an average difference between the two learning models.

When compared between the acquisition value of learning outcomes of participants in the control class with the value of learning outcomes obtained in the experimental class, there is an increase in the acquisition of learning outcomes in the control class by 1.97, while in the experimental class there is an increase of 2.83. Even though the pretest average score for the experimental class was slightly lower (3.57), the control class was slightly higher (3.70). Thus, it can be said that the increase in the average post-test score of the experimental class is greater than the control class, due to the influence of the discovery learning model used. It can be said that the discovery learning model is effective in the teaching and learning process of writing descriptive text. The results obtained, show that participants who learn with discovery learning models provide better results than participants who learn with conventional models. This is possible because the learning process has changed, from the beginning a teacher centered learning paradigm to a learning orientation that emphasizes a participant-centered learning process, which gives participants the opportunity to construct their own knowledge. In this case it is supported by Prasetyo \& Stin (2020) that the learning outcomes and critical thinking of experimental class students are higher than the control class. and this finding is in line with the opinion of Poedjiadi (2017) "that the discovery learning model can improve the learning achievement of participants by increasing the understanding of the meaning of the subject matter being learned by linking the material studied with the context of everyday life". Learning models that are constructivist are effective for improving participant learning outcomes.

In the learning process with the discovery learning model, participants are given tasks ranging from looking for learning resources themselves, finding the relationship between the material being studied and real life, summarizing, and discussing in heterogeneous groups of five participants, presenting or demonstrating to reflecting on their work. When students are given a writing assignment and describe students have 
good writing skills. They found that during the learning process students became active participants and when they took the test they knew what to write correctly even though some students were still lacking in grammar. This can be seen from the student learning outcomes on the test scores in each cycle. This is in line with what was written by Sobari \& Hanussalam (2019) that action research was carried out at MA Nurul Hidayah. Based on the results of their classroom action research it was concluded that the use of discovery learning method could improve the writing skills of class $X$ students.

In this lesson, at the beginning of the lesson, participants are encouraged to know and plan in advance what is needed and what they will do in learning activities. So that they become more motivated to be involved in group discussion activities and class discussions. Class discussion activities in this learning can improve the quality of the learning process, where the participants of the learning subject interact with each other to convey, respond to, and answer opinions and questions raised by other friends. This learning starts from the efforts of each individual in the group or collectively looking for learning resources which are continued with group discussions, in groups the participants are obliged to help each other, because the success of the group depends on the success of each individual in the group. Thus there is an increase in interaction between participants in the group so that smart participants will be able to improve and bring out their abilities while participants who are less smart can be helped by smart participants. In addition, participants who were initially less intelligent will become experienced and accustomed to the methods of learning carried out by their smart friends, automatically they will get experience about how to learn from other friends. so that the learning experience greatly motivates and increases student interaction and writing skills (Musyawir \& Loilatu (2020), and this fact is supported by the statement of Slavin (1995) that learning in small groups can stimulate the development of thinking and problem-solving abilities, and can meet the social needs and academic achievement of participants is much improved when compared to traditional learning.

In addition to these findings, there are other facts that show that the ability to understand the concepts and inquiry of participants who learn using the discovery learning model is better than those who learn using the conventional model. The overall post-test score in the experimental group, the highest was 9.0, the lowest, 6.5 the average was 7.40 , while the participants who got nilai 7.0 were 25 people $(83.3 \%)$. While the overall score of the post-test results in the control class, the lowest was 4.0, the highest was 7.0, on average, three people $(10 \%)$ scored nilai 7.0 . Thus, classically, the participants' learning completeness in the experimental class reached $83.3 \%$, while the control class was $10 \%$. From the findings above, it is evident that the ability to understand the concept and the ability of the participants to inquiry develop better in participants who take English learning using the discovery learning model. This interpretation means that each participant will rank almost equally well on conceptual understanding and inquiry abilities. This is in line with Musyawir \& Loilatu (2020) that discovery learning can improve writing skills and increase understanding of the material received by students during learning.

\section{CONCLUSIONS}

Based on the research conducted, it can be seen that there are significant differences between the ability to master concepts, inquiry abilities, and abilities between discovery learning models and conventional models. Then the student response to learning discovery learning is good as shown by the satisfaction of students in learning, as well as 
a positive response in learning English. This research is only limited to being carried out at the Surabaya Religious Education and Training Center with the existing conditions, so it is necessary to have a broader future research to carry out the same testing model with different conditions and environments. So that it can support and strengthen this research.

\section{ACKNOWLEDGEMENTS}

The researcher would like to thank all those who have contributed to this research. Thank you to all parties, especially the Surabaya Religious Education and Training Center.

\section{REFERENCES}

Al Muchtar, S. (2012). Pengembangan berpikir dan nilai dalam pendidikan. Bandung: Gelar Pustaka Mandiri.

Ariyana, Enawar, Ramdhani, I. S., \& Sulaeman, A. (2020). The application of discovery learning models in learning to write descriptive texts. Journal of English Education and Teaching, 4 (3).

Brown, D. (2008). Prinsip pembelajaran dan peengajaran bahasa. Jakarta: Pearson Education. Bruner, J. (1986). Actual minds, possible worlds. Cambridge, MA: Harvard University Press.

Creswell, J. W. (1994). Research design qualitative \& quantitative approaches. London, New Delhi: Sage Publications.

Departemen Pendidikan \& Kebudayaan. (2016). Peraturan menteri pendidikan dan kebudayaan no. 22 tahun 2016 tentang standar proses pendidikan dasar dan menengah. jakarta: depdikbud.

Druckman, D., \& Ebner, N. (2018). Discovery learning in management education: design and case analysis. Journal of Management Education, 42(3), 347-374.

Ellizar, E., Hardeli, H., Beltris, S., \& Suharni, R. (2018). Development of scientific approach based on discovery learning module. IOP Conference Series: Materials Science and Engineering, 335(1), 012101.

Gayatri, E. R. P., Bahar, A., \& Handayani, D. (2017). Perbandingan penerapan model pembelajaran learning cycle (5e) dan two stay two stray. Alotrop, 1(1).

Glynn, S. M. \& Scott, A. K. (2007). Implementing contextual teaching and learning: case study of sarah, a middle school science novice teacher. University of Georgia.

Hanafi. (2016). The Effect of discovery learning method application on increasing students' listening outcome and social attitude. Jurnal Dinamika Ilmu, 16 (2).

Jayanto, I. F., \& Noer, S. H. (2017). Kemampuan berpikir kreatif dengan pembelajaran guided discovery. Prosiding Seminar Nasional Matematika dan Pendidikan Matematika, 1(1), 253-263.

Kartika, Y., Hutapea, N. M., \& Kartini, K. (2020). Mathematical learning development using discovery learning model to improve mathematical understanding skills of students. Journal of Educational Sciences, 4(1), 124-132.

Kartodirdjo. (2009). Model Pembelajaran pengemas awal (advance organizer) dalam implementasi kurikulum bahasa di sd yang menggunakan pendekatan kronologis dalam rangka mengembangkan aspek ketrampilan kebahasaan. Makalah Perkuliahan, UIN Malang, tidak diterbitkan.

Khabibah, E. N., Masykuri, M., \& Maridi, M. (2017). The effectiveness of module based on discovery learning to increase generic science skills. Journal of Education and Learning, 11(2), 146-153. 
Krisnawati, E. (2015). The implementation of teaching writing using discovery learning to the eighth grade students at SMPN 1 Grogol in academic year 2014/2015. Unpublished Thesis: English Department, University of Nusantara PGRI Kediri.

Liswati, L. (2017). Penerapan kombinasi model kooperatif dan discovery untuk meningkatkan interaksi sosial dan aktivitas belajar pkn siswa sekolah dasar. Jurnal Kajian Pembelajaran dan Keilmuan, 4(2), 144-152.

Mufida, I. (2015). The implementation of discovery learning to teach speaking at the first grade students of SMP Institut Indonesia. Unpublished Thesis: Muhammadiyah University of Surabaya.

Mukharomah, L. (2015). The use of discovery learning model to improve students' descriptive text writing: A classroom action research at VII A Class of MTs NU 08 Gemuh Kendal in the Academic Year of 2014/ 2015). Unpublished Thesis: Walisongo State Islamic University Semarang.

Musyawir, M., \& Loilatu, S. H. (2020). Kemampuan menulis karangan narasi berdasarkan pengalaman pribadi siswa: (The ability to write a narrative essay based on students' personal experiences). Uniqbu Journal of Social Sciences, 1(2), 1-12.

Poedjiadi, A. (2017). Sain teknologi masyarakat, model pembelajaran kontekstual bermuatan nilai. Bandung: Remaja Rosdakarya.

Prasasti, D. E., Koeswanti, H. D., \& Giarti, S. (2019). Peningkatan keterampilan berpikir kritis dan hasil belajar matematika melalui model discovery learning di kelas IV SD. Jurnal Basicedu, 3(1), 174-179.

Prasetya, T. A., \& Harjanto, C. T. (2020). Improving learning activities and learning outcomes using the discovery learning method. VANOS Journal of Mechanical Engineering Education, 5(1).

Prasetyo, F., \& Kristin, F. (2020). Pengaruh model pembelajaran problem based learning dan model pembelajaran discovery learning terhadap kemampuan berpikir kritis siswa kelas 5 SD. Jurnal Pendidikan Guru Sekolah Dasar, 7(1), 13-27.

Putri, A., Roza, Y., \& Maimunah, M. (2020). Development of learning tools with the discovery learning model to improve the critical thinking ability of mathematics. Journal of Educational Sciences, 4(1), 83-92

Rahman, M. H. (2017). Using discovery learning to encourage creative thinking. International Journal of Social Sciences \& Educational Studies, 4(2), 98.

Safaruddin, Degeng, I. N. S., Setyosari, P., \& Murtadho, N. (2020). The effect of PJBL with WBL media and cognitive style on students' understanding and science-integrated concept application. Jurnal Pendidikan IPA Indonesia, 9(3), 384-395. https://doi.org/10.15294/jpii.v9i3.24628

Sayuti, S. A. (2014). Menuju Pengajaran Sastra yang Ideal. Makalah seminar tidak diterbitkan. Malang: Fakultas Sastra Universitas Negri Malang.

Shellawati, S., \& Sunarti, T. (2018). Penerapan model pembelajaran inkuiri terbimbing untuk meningkatkan kemampuan literasi sains peserta didik SMA. Inovasi Pendidikan Fisika, 7(3).

Sirait, M. (2017). Model pembelajaran berbasis discovery-inkuiri dan kontribusinya terhadap penguatan kualitas pembelajaran di sekolah dasar. AR-RIAYAH: Jurnal Pendidikan Dasar, 1(2), 155-170.

Slavin. (1995). The cycle of learning. Cambridge: Cambridge University Press.

Sobari, M. R., Hanussalam, H. (2019). The use of discovery learning method to improve students' writing descriptive text. Professional Journal of English Education, 2 (2). 
Sulfemi, W. B. (2019). Penerapan model pembelajaran discovery learning meningkatkan motivasi dan hasil belajar pendidikan kewarganegaraan. Jurnal Rontal Keilmuan Pancasila dan Kewarganegaraan, 5(1).

Syarif, E., Syamsunardi, S., \& Saputro, A. (2020). Implementation of discovery learning to improve scientific and cognitive attitude of students. Journal of Educational Science and Technology (EST), 6(1), 23-31.

Wiriaatmadja, R. (2012). Pendidikan di Indonesia. Bandung: Historia Utama Press.

Yerizon, Y., Putra, A. A., \& Subhan, M. (2018, April). Student responses toward student worksheets based on discovery learning for students with intrapersonal and interpersonal intelligence. IOP Conference Series: Materials Science and Engineering, 335(1), 012113).

Yurniwati, \& Hanum, L. (2017). Improving mathematics achievement of indonesian 5th grade students through guided discovery learning. Journal on Mathematics Education, $8(1), 77-84$.

\section{* Dr. Widayanto (Corresponding Author)}

Religius Education and Training Center Surabaya, Indonesia

Jl. Ketintang Madya No.92, Karah, Kec. Jambangan, Kota SBY, Jawa Timur 60232

Email: widoyantoku@gmail.com 